\title{
THE EFFECTS OF EUROPEAN ECONOMIC INTEGRATION AND THE IMPACT OF BREXIT ON THE UK IMMIGRANTS FROM THE CEE COUNTRIES
}

\author{
Mihaela Simionescu, Yuriy Bilan, Luboš Smrčka, \\ Zuzana Vincúrová
}

\section{Introduction}

Even if most immigrants come from nonEU states, the EU membership is often considered as the UK's perceived migration issue. Immigration is an actual problem in the UK and one of the main causes of Brexit. The debate regarding the immigrants issue is mostly referred to less developed countries from Central and Eastern Europe which joined the EU the latest. Some Britons considered that immigrants exerted high pressure on public services. Contrary to this opinion, Petroff (2016) showed that immigrants contribute to the country's budget and stimulate economic growth. Most immigrants come to work and therefore, they pay taxes. Moreover, they often compensate for the ageing local population. According to the Brexit scenario, migration will be limited, which from the economic point of view implies lower economic growth and higher burden of the exchequer.

According to the principle of free movement of persons, goods, services and capital, nonBritish EU citizens have the right to work in the UK (Boswell, 2016). As Staiger (2016) explained, the UK can completely control its borders and it is exempt from common standards in immigration and some asylum regulations. The number of the UK immigrants from the CEE countries increased after their entrance into the EU, but actually most of these emigrants preferred such countries as Germany, Spain, Italy and France (Čajka et al., 2014; Tilford, 2015).

Rumpel et al. (2013) showed that migrants from CEE countries prefer cities or urban regions because of the employment opportunities. Moreover, microeconomic determinants of migration were identified by Merkevicius et al.
(2015) who consider that deficiencies in human resources management in the developing countries determined migration in developed countries.

The main aim of this paper is to evaluate the question of migration in the context of economic development in the UK, to show the positive impact of the UK immigrants from the CEE countries on the UK economy after their economic integration, and the possible negative consequences of Brexit on the migration process from some CEE countries to the UK. We will focus only on the increase of the number of UK immigrants from these countries due to the EU membership, making comparisons with other CEE countries that did not entered the EU. The sample of the CEE countries was selected to include the available data on ethnic communities with a consistent number of immigrants. Due to the nature of data and the existence of some mixed effects in explaining the emigrants' behaviour, some specific Poisson models were estimated. Moreover, a counterfactual analysis by comparing the EU countries with the group represented by Russia, and Ukraine was conducted. The influence of Brexit itself might reduce the number of immigrants from the CEE countries twofold, and potential future migration policies may reduce it further. The CEE emigrants might come back home or they can go to other EU countries (countries with a large number of CEE immigrants or on the opposite, to the countries with less immigrants).

Moreover, we empirically check the assumptions regarding the impact of CEE countries' emigrants on the main macroeconomic indicators in the UK, proving that the results are consistent with the previous 
studies on the immigrants overall. Emigrants from the CEE countries had a positive impact on the UK economy and their arrival in the UK should be stimulated after Brexit.

The paper is organized as follows. After the Introduction, a literature review is presented. The methodological framework is set up and the empirical results are interpreted. Conclusion is the final part of the paper.

The paper is organized as follows. After the Introduction, a literature review is presented. The methodological framework is set up and the empirical results are interpreted. Conclusion is the final part of the paper.

\section{Literature Review}

This research focuses on the impact of economic integration and Brexit on the UK immigrants from less developed countries, namely, from the CEE. This assessment is necessary because both public opinion and literature show positive and negative effects of immigration on the UK economy. Our position is consistent with the empirical findings presented in economic literature that show the positive impact of the EU immigration on the UK. In this case, the reduction of EU immigrants after Brexit will bring along lower economic growth and austerity measures. One of our tasks is to measure the decrease in the number of the UK immigrants from the CEE countries and to propose policies to alleviate this decline.

Considering any sort of economic integration, four freedoms specific to internal markets are affected: free movement of goods, persons, services and capital. In this context, Ebell and Warren (2016) showed that EU membership had a positive impact on the UK immigrants, because of free movement of capital and because of free movement of goods and services, including labour mobility and passporting that made the UK an attractive destination for emigrants from the entire Europe. Robinson (2015) stated that probably the most important consequence of Brexit would affect the movement of capital that will affect businesses by bringing more uncertainty. Investment would fall as a result, especially by footloose multinationals who would find the UK a less attractive location. The resulting damage to the UK's long term prospects for growth in national income, and hence company revenues and profits, could have a negative impact on the share prices.
According to economic theory, mobility of production factors ensures better resource allocation at international level which brings along welfare increase (Grosu \& Dinu, 2016). This applies to capital (Jäger-Ambrożewicz \& Matthes, 2012) and also to labour mobility even if the policies are very sensitive to the migration problem (Lodewyckx et al., 2010; Giovanni et al., 2012; Wadsworth, 2015; Aichele \& Felbermayr, 2015). According to the endogenous growth theory, a liberal trade mode generates benefits to the industries with an obvious competitive advantage (Rebelo, 1991; Romer, 1994; Vitunskiene \& Serva, 2015; Stefaniak-Kopoboru \& Kuczewska, 2016). This theory proves that faster economic growth can be achieved through specialisation and the reduction of product unit costs. Taylor et al. (1993), Duczynski (2000) noted that countries with higher level of trade openness have higher opportunities to exploit technological innovations, which also determines faster pace of their economic growth. According to the product life cycle theory, having standardized product technologies, companies tend to relocate their production to countries with comparatively low capital intensity (Hirsch, 2009; Farmer \& Schelnast, 2012). This is the reason for advanced innovations and technologies flow from leading economies to followers via trade openness. Greater rate of innovation and technology absorptions promotes the raise of human resources skills and capacities (Balcerzak, 2016), which, in turn, leads to economic growth in the long run (Pilinkiene, 2016).

The Central and Eastern European Countries (CEEs) are experiencing high growth rates in terms of trade openness. The total trade openness index for the CEEs in 2014 reached 136.4 percent, and in comparison to 2000 increased by 45 percent. Slovak Republic (trade openness index is equal to $180 \%$ ), Estonia $(167 \%)$ and Lithuania (163\%) are attributed to CEEs countries with the highest degree of trade openness whereas Romania (82\%) and Poland $(78 \%)$ show the lowest degrees in this respect. It is important to note that trade openness index for the least trade open CEEs is equal to the average of the EU (81.3\%), which proposes that the old EU member-states are substantially more closed for international trade, but have higher degree of competitiveness. With the reference to the data of the World Economic 
Forum, in 2014 Germany, one of the most competitive EU states, occupied the 5th position in the Global Competitiveness Index, but had trade openness index equal to 85 percent, i.e. slightly higher than the EU average. Hence, it is purposeful to research whether higher degree of country's competitiveness leads to lower degree of trade openness and vice versa, and to define the conditions for this interrelation (Pilinkiene, 2016; Lelek, 2014).

A major argument for Brexit was the possibility to control more the immigration to the UK from the other EU countries. The level of net inward migration has been at record high levels in recent years, with the latest data showing net inflows of 323,000 over the year to Q3 2015. Net immigration from the EU countries was 172,000 over this period, only a touch lower than 184,000 recorded over the year to Q1 2015 (Goodwin, 2016). British population common perception is that uncontrolled immigration will affect their wages, their jobs and overall life quality. Immigration reduction is demanded by a high percentage of population (between $44 \%$ according to Ipsos-Mori and $71 \%$ according to 5 News and YouGov) because of the burden on public services, salaries, unemployment and cultural issues (Boswell, 2016). 58\% of the Britons consider that the EU emigrants should first have a definite job, before their arrival in the UK (Daily Express, 2016).

Economists have a different perception of the migration issue. Most of the arguments encourage the EU immigration. Usually, these immigrants are younger, more educated and ready to work, having fewer benefits than the UK-born. While the Britons are concerned with higher competition for jobs, immigrants would actually use services and goods, thus increasing the overall demand and creating more job opportunities. Moreover, immigrants might have complementary skills. There are many studies analysing the impact of immigration on jobs and salaries of the UK-born workers (Wadsworth, 2015; Portes, 2016; Dustmann et al., 2005). All these studies indicated that immigration increase did not significantly affect jobs and salaries of the UK-born workers in a negative way. The empirical evidences of Wadsworth et al. (2016) suggested that the zones with high growth in the EU immigrants did not registered greater fall in jobs and wages paid to the UKborn people. The real cause for the decrease in salaries after 2008 was in fact the world financial crisis and the problems with achieving fast economic recovery but not the immigration increase. On the other hand, there is little evidence regarding less jobs and salaries for low skilled UK-born workers because of the EU immigrants that are more educated.

Immigrants bring in extra resources that might be further used to increase spending on local health and education for the UK-born people. By reducing the EU immigration greater austerity is required. The economic literature demonstrates a consensus regarding positive effects of foreign direct investment and trade on the UK productivity. But there is less of a consensus regarding the consequences of immigration on productivity in the UK. Previous studies found a strong evidence for positive effects in case of more educated immigrants ((Ortega \& Peri, 2014; Ottaviano et al., 2016) for the UK service productivity). For overall immigration, most of empirical researches detected positive or even insignificant effects. An evaluation carried out by Felbermayr et al. (2010) showed that a $10 \%$ increase in the immigrant stock generates the gain of $2.2 \%$ in per capita income in general.

The EU immigrants diminish the budget deficit, because they pay more taxes as compared to the money for welfare and utilization of public services. Immigrants do not negatively affect the local services on the problems regarding education, healthcare, crime or social housing.

Regarding the impact of immigrants on public finances, Dustmann and Frattini (2014) showed that the EU immigrants have a positive fiscal contribution by paying more taxes than getting benefits in terms of welfare. On the other hand, the UK-born citizens receive more benefits than they pay taxes. Springford (2013) and Milaszewicz et al. (2015) considered that the main determinant of the migration from the CEE countries to the UK is the welfare gap. Springford (2013) showed that only 0.8 percent of the EU immigrants received unemployment benefit one year after their arrival in Britain. Most immigrants come to Britain only to find jobs and not for higher welfare. $71 \%$ of immigrants come to the UK for jobs and $6 \%$ of them are unemployed, but they do not require allowance support (Petroff, 2016).

The Office for Budget Responsibility (2013) forecasted a national debt for UK by 40 percentage points higher till 2062 if 
net immigration will become null. If the EU immigrants are net contributors, there is not any evidence they will ask for public services. They bring more resources that might be used to increase spending on education and healthcare for the UK-born people. Reduction of the EU immigration would bring greater austerity. Dhingra et al. (2016) showed that one of the measures in these cases would be cutbacks determined by slower economic growth. The cutting backs on public services could not be attributed to immigrants.

Some Britons claim about that social disruptions are often caused by immigrants, but their assumption has no proof when it comes to the actual crime rates. The empirical findings of Bell et al. (2013) suggested that high increase in immigration after 2004 when many East European countries entered the EU did not have any impact on crime level as such.

There is also no impact of immigration on educational attainment as proved Geay et al. (2013). The immigrants' pupils work hard at school to overcome the disadvantage of having English as a second language.

The EU immigrants are younger than nonEU ones and the chances to use healthcare services are thus fewer. Moreover, Wadsworth (2013) explained that there is lower usage of hospitals and doctors by immigrants as compared to the UK-born. Giuntella et al. (2015) found little effect of immigration on the waiting time in the National Health System.

The perception that immigrants receive better treatment when they apply for social housing is declined by Battiston et al. (2013) who showed there are lower chances for immigrants to be in social housing.

Many Britons are concerned about the impact of immigration on housing prices. Housing supply is low even if disregarding the EU immigrants. The main reason is a weak planning system that does not provide suitable infrastructure decisions (Hilber, 2015). Moreover, Sa (2015) emphasized there is no empirical evidence that immigration had a positive impact on house pricing.

All these arguments basing on the empirical evidences show that immigration has positive effects on the UK economy. The following issue discussed in literature is related to immigration restrictions after Brexit. Our research shows that the number of immigrants in the UK from the CEE countries will automatically decrease in a natural way. In this context, the UK policies should be oriented towards the attraction of new immigrants. Restrictions reducing the CEE emigration will not be beneficial for the UK economy.

If the UK will remain the member of the European Economic Area or European Free Trade Area, it should apply no restrictions on the EU immigration, like Switzerland and Norway do today. Restriction could appear when the UK imposes a looser trading agreement with more trade costs. A visa scheme might be adopted like in the case of non-EU countries if the UK wants to reduce the number of EU immigrants after Brexit. Moreover, the UK will cut the skilled EU immigration that might not be replaced with non-EU skilled immigration. The skills' gap will be narrower because when the job market becomes saturated, labour immigrants will be rejected and thus they will leave the UK.

Office for Budget Responsibility (2015) forecasted an increase in unemployment of 60,000 people which will also affect immigrants. After Brexit, the minimum salary is expected to increase. Growing productivity brought by immigrants might increase national wages. However, in the lack of labour force with high productivity, wages might not increase. By cutting the EU immigrants to 80,000 people per year, Boubtane et al. (2015) showed that labour productivity might decrease by $0.16 \%$ and in 10 years after Brexit GDP per capita could be 1.6\% lower as compared to the case when UK would have remained in the EU.

Migration Watch considered that the UK needs a stable population growth and this might be achieved by bringing migration back to its level of the 1980s and 1990s. The reconsidered policies should ensure increasing outflows and a more temporary migration. ITV (2016) considers that free movement end will not reduce dramatically the number of immigrants, but our empirical evidence will show that this impact will be very large.

The people who sustained Brexit considered that the EU migration will be controlled, but in case of trade agreements with the EU there will be still free movement of persons for the EU citizens like in Switzerland and Norway.

If the UK follows the Norway model, it has to accept free movement of persons and also higher proportion of the EU immigrants than it prefers (Staiger, 2016). If the Switzerland model will be taken into account, only partial access to 
the Single Market is allowed, with uncontrolled immigration from Europe.

After Brexit, Boswell (2016) and Booth (2015) proposed policies ensuring better wages and better training and education of British labour force mostly in the construction sector. Drastic reduction of labour will have damaging effects on such sectors as food processing, manufacturing, cleaning, health, and tourism (Boswell, 2016). Migration reduction while stabilizing the population rate might bring along negative trade-offs and costs; mostly in lowsalary sectors like the care work (The Migration Observatory, 2012).

Boronska-Hryniewiecka (2016) considers that the output will decrease by more than $1 \%$ by 2010 if the number of immigrants is reduced annually by 100,000 people. Government policies could focus more on skills rather than on workers' origin countries. This policy might promote the productivity growth, according to Woodford (2016). After Brexit, the immigrants' unemployment could rise and the salary could decrease. In case of a significant reduction in the number of immigrants as we stated, the benefits for even highly skilled sectors are rather doubtful (Boronska-Hryniewiecka, 2016; Boswell, 2016). Chu (2016) considers that the decrease in economic performance after Brexit might be alleviated if immigration reduction becomes insignificant. This will help GDP stabilize and the income per capita will grow. A liberal policy on migration will increase GDP till 2030, according to Booth (2015). For covering the necessity in low-skilled jobs, the UK might continue receiving the EU immigrants.

In the case of post-Brexit points system, the solutions might include a specific temporary migration scheme for the EU migrants or preferential treatment for these migrants (Ruparel, 2016). Another scenario might be the bilateral agreements with the selected EU states.

PwC (2016) proposed a CGE model for the UK economy to measure the effects of changes in migration policies after Brexit. The long-run impact on the UK economy is related to lower long-term potential growth as compared to the situation of remaining in the EU. Less flexibility of the labour market is expected after Brexit and a more cyclical economy with more frequent recessions.

Taken into account the anticipated effects of Brexit on immigration and further negative consequences on economic growth due to immigration, we consider necessary to assess Brexit impacts on immigration. Moreover, some policy measures are proposed to alleviate the negative consequences for the UK economy. To achieve this goal, a specific methodology is proposed here. It is described in the next section.

\section{Methodology and Data}

In this paper, two types of methods are applied to explain the number of immigrants in the UK when the origin countries are represented by some CEE states: mixed-effects Poisson regression models and counterfactual analysis based on difference-in-difference estimator. The mixed-effects Poisson models are employed when we want to analyze the counts number in a period (in our case, the number of immigrants in the UK in a certain period). Mixedeffects models include both fixed and random effects. These models allows for predictions of unobserved levels of random-effects factors. The Poisson models based on count data eliminate the necessity of normal distributed errors. Difference-in-difference estimator is an approach used to make comparison between two groups of countries before and after an event: treatment group (the CEE countries that are in the EU) and control group (the CEE countries that are not members of EU). The event considered in this study is the entrance in the EU of some CEE countries.

The mixed-effects Poison regression model describes the expected counts number in a certain period when specific events are registered $\left(t_{i j}\right)$ :

$$
E\left(y_{i j}\right)=\mu_{i j}=t_{i j} \exp \left[x_{i j}^{\prime} \beta+z_{i j}^{\prime} \vartheta_{i}\right]
$$

where

$i=1,2, \ldots, \mathrm{N}$ level -2 units which are for clusters.

$j=1,2, \ldots, \mathrm{n}_{\mathrm{i}}$ level -1 units which are for multiple observations.

$y_{i j}-$ dependent variable counting the number of events.

$t_{i j}$ - period when the events are registered (this is the offset variable).

$t_{i j}=t$, when all observations are related to the same period when the events are registered.

$t_{i j}$ varies if the observations are related to varying periods; this variable is essential in modelling process. 
$x_{i j}$ - covariates at the first, the second level or cross-level interactions; this variable can include polynomials, dummy variables, interactions etc.

$\beta$-regression coefficients corresponding to covariates.

$z_{i j}$ - random effect variable or variables that can be, mostly, an intercept for longitudinal data and for clustered data or time.

$\vartheta_{i}$ - random effects that follow a normal distribution of null average and a certain variance-covariance matrix $\Sigma_{\vartheta}$.

The random effects describe how a certain cluster $i$ influences the observations within the cluster and the way in which a cross-section starts and makes any progress in time.

$$
\begin{aligned}
& \log \left(\mu_{i j}\right)=\log \left(t_{i j}\right)\left[x_{i j}^{\prime} \beta+z_{i j}^{\prime} \vartheta_{i j}\right] \\
& \log \left(\mu_{i j}\right)=\log \left(t_{i j}\right)=x_{i j}^{\prime} \beta+z_{i j}^{\prime} \vartheta_{i} \\
& \log \left(\mu_{i j} / t_{i j}\right)=x_{i j}^{\prime} \beta+z_{i j}^{\prime} \vartheta_{i}
\end{aligned}
$$

In case of the Poisson regression, the link function is represented by the log link function. The incidence (event rate ratio or) is equalled to $\exp \beta$.

If an offset variable is not included in the model, the mixed-effects Poison regression is expressed as:

$$
\log \left(\mu_{i j}\right)=x_{i j}^{\prime} \beta+z_{i j}^{\prime} \vartheta_{i}
$$

The model with offset variable is represented as:

$$
\log \left(\mu_{i j}\right)=\log \left(t_{i j}\right)+x_{i j}^{\prime} \beta+z_{i j}^{\prime} \vartheta_{i}
$$

The logarithm of the offset variable works as an explanatory variable having a slope equalled to 1. For Poisson models, we consider that the mean and the variance are equalled. The overdispersion is specific to cases when the variance is higher than the mean. This overdispersion, often met in a real data, produces estimated distortion. The chances of overdispersion can be considerably reduced by including random effects and the individual differences. For a Negative Binomial model, an overdispersion parameter is considered for relaxing this assumption. In other words, the Poisson model is a special case of the Negative Binomial Model when the overdispersion parameter is zero.

Gibbons et al. (2008) described three methods of estimating the parameters of a Poisson regression: parametric fully
Bayes (FB) or semi-parametric estimation and empirical Bayes (EB) estimation. The differences between approaches consist in the different ways of specifying and estimating the random coefficients vector distribution. A normal distribution is considered for parametric FB and EB. The distribution's coefficients for EB method are inferred using point estimation in case of maximum marginal likelihood. The inference uses posterior distribution for FB method. In the case of semi-parametric FB estimation, a non-parametric prior is associated to random effects distribution. The EB approach has as a disadvantage the assumption of known random effect covariance matrix. FB approaches overcome this limit by including a prior distribution for the coefficients that are associated to random effects distribution. Parametric FB method employed by El-Sayyad (1973) makes inferences for mixed-effects Poisson regressions, an improper prior being considered. For large shape parameter the distribution for gamma variable logarithm is approximated by the normal distribution. In this case, the posterior density follows a multivariate normal repartition. A more flexible approach is the semi-parametric FB method, because Dirichelet process stands for the entire space of repartitions corresponding to random effects. All the normal distributions are included.

For making comparisons between groups after a certain treatment or intervention, the entrance into the EU in our case, the differencesin-Differences (DD) estimation might be used. It is used to estimate causal relationships. The differences in outcomes (number of the UK emigrants from some CEE countries) are compared before and after the entrance into the EU for countries that supported the intervention to the same difference for states that did not become EU member states. Beside its simplicity, the DD approach surpasses many issues regarding the endogeneity determined by comparisons between heterogenous cross-sections (Meyer, 1995). The method is recommended for random interventions which are conditioned by fixed effects and time. In case of intervention's endogeneity the results become invalid. In many cases, DD estimators and the associated standard errors use the Ordinary Least Squares on cross-section or panel data. In this particular research, there are countries in treatment (those that entered into the EU at a certain time) and control countries 
for years before and after the European economic integration. If $Y_{i s t}$ is the outcome for country $i$ from group $s$ (country $s$ ) by moment $t$, a dummy variable $I_{s t}$ is included for marking the effect of the intervention (entrance in the EU) of that group at a certain moment.

$$
Y_{i s t}=A_{s}+B_{t}+c X_{i s t}+\beta I_{s t}+e_{i s t}
$$

$A_{s}, B_{t}$ - fixed effects.

$X_{i s t}$ - individual control.

$e_{i s t}-$ error term.

The impact of the intervention is measured by the estimate of $\beta$. The confidence intervals are based on this parameter and the OLS standard error that are sometimes corrected with the shocks' correlation in each country and each year. The presented specification is the general form of the DD estimation with 2 periods and 2 groups. The results are valid if the changes in time in the dependent variable would have been the same in both groups in the lack of the intervention I. When errors' serial correlation occurs, the t-statistics and the associated significance levels are overestimated. There are various causes for serial correlation, but different procedures are employed for correcting it.

In this study, the dependent variable refers to the number of immigrants in the UK where the origin countries are represented by some of the Central and Eastern Europe (CEE) states: Poland, Bulgaria, Romania, Latvia, Lithuania, the Czech Republic, Cyprus, Slovakia, Hungary, Russia and Ukraine. Excepting the last three countries, all the other ones are member states of the European Union. These particular CEE countries were selected from the representative sample of 60 countries with the significant number of emigrants in the UK. For the other CEE countries the data are not available and the number of emigrants is not too high. The explanatory variables are represented by: real GDP per capita, real wage, distance between London and the capital of each state and unemployment rate in these origin countries for immigrants. A dummy variable called the EU member is introduced to mark the states that are in the EU from a certain year. The models are based on panel data, covering these 12 countries and the period from 2004 to 2014. Bulgaria and Romania entered into the EU in 2007, while the rest of the mentioned CEE states, excluding Russia and Ukraine, are the members since 2004. The number of immigrants was taken from the database of the Office for National Statistics in the UK. The distances were measured in kilometres and they refer to air distances, being provided by http://www.distancefromto.net/. The data for the rest of the variables are provided by the World Bank.

Tab. 1: The number of UK immigrants from some CEE countries (thousands persons)

\begin{tabular}{l|r|r|r|r|r|r|r|r|r|r|r}
\multicolumn{1}{c|}{ Country } & $\mathbf{2 0 0 4}$ & $\mathbf{2 0 0 5}$ & $\mathbf{2 0 0 6}$ & $\mathbf{2 0 0 7}$ & $\mathbf{2 0 0 8}$ & $\mathbf{2 0 0 9}$ & $\mathbf{2 0 1 0}$ & $\mathbf{2 0 1 1}$ & $\mathbf{2 0 1 2}$ & $\mathbf{2 0 1 3}$ & $\mathbf{2 0 1 4}$ \\
\hline Poland & 69 & 137 & 249 & 399 & 502 & 538 & 564 & 654 & 713 & 736 & 790 \\
\hline Lithuania & 22 & 31 & 54 & 57 & 61 & 80 & 99 & 131 & 143 & 161 & 170 \\
\hline Czech Republic & 12 & 20 & 24 & 25 & 26 & 30 & 37 & 41 & 43 & 42 & 47 \\
\hline Romania & 10 & 15 & 14 & 19 & 37 & 57 & 78 & 98 & 108 & 135 & 170 \\
\hline $\begin{array}{l}\text { Cyprus (Euro- } \\
\text { pean Union) }\end{array}$ & 10 & 12 & 12 & 17 & 22 & 25 & 17 & 55 & 21 & 13 & 15 \\
\hline Bulgaria & 9 & 12 & 14 & 15 & 29 & 35 & 46 & 50 & 56 & 51 & 65 \\
\hline Slovakia & 9 & 24 & 47 & 50 & 45 & 54 & 50 & 61 & 66 & 55 & 68 \\
\hline Hungary & 7 & & 12 & 18 & 22 & 26 & 37 & 48 & 50 & 73 & 88 \\
\hline Latvia & & 13 & 18 & 21 & 29 & 27 & 49 & 61 & 71 & 89 & 101 \\
\hline Russia & 21 & 20 & 19 & 21 & 27 & 19 & 28 & 43 & 37 & 35 & 31 \\
\hline Ukraine & 9 & 10 & 13 & 17 & 15 & 14 & 13 & 12 & 13 & 17 & 19 \\
\hline
\end{tabular}


As Tab. 1 shows, the most UK immigrants from the CEE countries are from Poland with an obvious tendency of increase over 20042014. Ukraine and Russia which are not the EU states are among the countries with the fewest emigrants to the UK. The number of Poland emigrants to the UK increased, in average, by 1.27 times over 2004-2014 and by 11.44 times in 2014 compared to 2004. After Poland's entrance into the EU, Great Britain was among the few countries that gave Polish people the right to work in the UK immediately. Around 2 million Poles left their country since 2004 and came in Britain being determined by high unemployment rate and low salaries in their state of origin. The Polish citizens represent the largest group of European foreigners in the UK. Like in the case of the other CEE countries, Polish people brought benefits to the Britain economy, because of the cheap labour force. According to Migration Advisory Committee Report (July 2014) immigrants from the CEE countries represent $3 \%$ of all employed people in UK. They work mostly in low-skill employment (4\% of labour force), less in high-skill employment ( $2 \%$ of labour force). The total number of immigrants from these CEE countries rose by 7 times in 2014 in relation to 2004.

The impact of immigration on main macroeconomic indicators in the UK, when the origin countries are in CEE, is assessed using Bayesian linear regression models over the period 2004-2014. These models are suitable for small sets of data, like in this case. The variables used in this analysis refer to: real GDP rate $(\%),(2005=100)$, inflation rate $(\%)$, unemployment rate $(\%)$, real interest rate $(\%)$, share of manufacturing, foreign direct investment (FDI) as a percent of GDP, the global competitiveness index, political stability, homicide rate, education spending as a percent of GDP, health spending as a percent of GDP, a number of the immigrants from the CEE countries.

The Global Competitiveness index is based on 12 pillars of competitiveness: basic requirements (Macroeconomic Stability, Infrastructure, Institutions, Health and Primary Education), efficiency enhancers (Goods Market Efficiency, Higher Education and Training, Labour Market Efficiency, Technological Readiness, Financial Market Sophistication, Market Size) and innovation and sophistication factors (Innovation, Business Sophistication). The global competitiveness index decreased from a year to another during 2007-2009 in the UK on the basis of the global economic crisis. A slow increase of the index was observed since 2010 with a lower decrease in 2013. Even if the Global Competitiveness Report 2015-2016 placed the UK on the 10th place in the world, the UK in the last few years faced problems like budget deficit, low quality of the education system and the difficulties countered by companies to take loans.

General government expenditure on education (capital, current, and transfers) as a percentage of GDP includes expenditure based on transfers from international sources to government. The source of data is represented by UNESCO. The education spending increased since 2008, but the education quality is still not at an acceptable level in the UK.

Total health expenditure indicator by the World Bank includes public and private health expenditure. It covers the family planning activities, provision of health services (curative and preventive), emergency aid for health and nutrition activities, but it does not include provision of sanitation and water. The health expenditure registered a very low average increase by $1.3 \%$ over that period.

Inflation based on consumer price index shows the annual percentage change of the cost of acquiring a basket of services and goods by the average consumer that could be fixed or changed at specified times, mostly yearly. The inflation rate registered a low average increase by $1.4 \%$. In the post Brexit period, a high increase in prices is expected.

The real interest rate which is the lending interest rate adjusted for the GDP deflator measured in percent is provided by the International Monetary Fund. Since 2009, the interest rate in the UK registered the negative values. There are a few reasons for this: the decline in the global interest rates because of the world financial crisis, distortions in the government bonds market, the secular trends to ensure the long-run decline.

Manufacturing takes into consideration the industries belonging to ISIC divisions 15-37. Value added represents a sector net output after adding up the outputs and subtracting intermediate inputs. Deductions for depreciation of fabricated assets or depletion and degradation of natural resources are not made. 
The value added is based on the International Standard Industrial Classification (ISIC), third revision 3 . The share of manufacturing begun to decrease since 2005 and since 2007 in the context of the economic crisis reached a value under $11 \%$.

Unemployment rate represents the share of the labour force without work, but seeking employment and available for the job. The data series for these variables and for political stability are provided by the World Bank. A high increase in the unemployment rate was registered in 2009, because of the world economic crisis, which translates into increase by $44.44 \%$ compared to 2008 . Since 2009 , the unemployment rate continued to increase, but in 2014 it reached a lower value of $6.3 \%$.
Homicide rate represents the number homicides per 100,000 people. The data series is provided by the UN office on drugs and crime. This indicator registered a persistent decrease over 2004-2014 with an average decrease of almost $6.5 \%$.

\section{Results}

The use of count data for dependent variable allows us to consider the Poisson models as the most suitable method of analysis. We work under the hypothesis that the quality of EU member is related to distance. There is a lower distance between London and the capitals of countries that are already EU member states.

\begin{tabular}{|c|c|c|c|c|}
\hline \multirow[t]{2}{*}{ Tab. 2: } & \multicolumn{4}{|c|}{$\begin{array}{l}\text { Mixed-effects Poisson model for explaining the number of UK immigrants (M1) } \\
\text { from main CEE (2004-2014) }\end{array}$} \\
\hline & Variable & Coefficient & z-calculated & $P>|z|$ \\
\hline Wage & & 0.0102 & 82.13 & 0.000 \\
\hline GDP per & sapita & -0.00034 & -78.15 & 0.000 \\
\hline Unemplo & ment rate & -0.085 & -22.23 & 0.000 \\
\hline EU mem & & 10.0523 & 40.02 & 0.000 \\
\hline Constant & & 2.8835 & 11.67 & 0.000 \\
\hline \multicolumn{5}{|c|}{ Random effects parameter } \\
\hline \multicolumn{2}{|c|}{ EU_member: independent } & Estimate & & \\
\hline \multicolumn{2}{|c|}{$\operatorname{sd}(\operatorname{In}($ distance $))$} & 0.00302 & 0.0010 & - \\
\hline \multicolumn{2}{|c|}{ sd(constant) } & $3.15^{*} 10^{-9}$ & 0.0503 & - \\
\hline
\end{tabular}

Prob. $>$ chi-square $=0.000$

Source: own

The M1 mixed-effects Poisson model indicated that the EU membership had a positive impact on the emigrants from the CEE countries that chose the UK as a destination country. The increases in the GDP per capita in the selected CEE countries had a very low and negative impact on the emigration process towards the UK.

Contrary to the expectations, unemployment rate had a negative effect on the number of the UK immigrants from the CEE countries while the wage had a positive effect. In case of Brexit, the number of immigrants from the CEE countries that are the EU members in the UK might decrease by $99.4 \%$, according to M1 Poisson model. However, the results should be cautiously considered, because many of the labour resources were not actually considered in the computation the unemployment rate in the origin country, being part of the underground economy.

The M2 mixed-effects Poisson model indicated again that the EU membership had a positive impact on the emigrants from CEE countries that chose the UK as a destination country. The distance is not relevant in explaining the immigration process in the UK from the CEE countries. The result is contrary to the conclusion of Hatton and Wiliamson (2005) for migration between continents. The correlation between GDP per capita and migration is still negative, but not so strong, 
Tab. 3: Mixed-effects Poisson model for explaining the number of the UK immigrants (M2) from main CEE (2004-2014)

\begin{tabular}{l|c|c|c}
\multicolumn{1}{c|}{ Variable } & Coefficient & z-calculated & P>|z| \\
\hline Distance & 0.0056 & 0.56 & 0.000 \\
\hline GDP per capita & -0.00003 & -21.74 & 0.000 \\
\hline EU member & 6.2386 & 28.55 & 0.000 \\
\hline Constant & -1.8926 & -6.48 & 0.000 \\
\hline Random effects parameter & & & \\
\hline EU_member: independent & Estimate & & - \\
\hline sd(In(distance)) & 0.0022 & 0.0009 & - \\
\hline sd(constant) & $2.56^{*} 10^{-8}$ & 0.0386 & \\
\hline
\end{tabular}

Prob. $>$ chi-square $=0.000$

because underground economy still could offer jobs in the origin country. In the case of Brexit, the result is consistent with the previous model. The number of immigrants in the UK from the CEE countries that are the EU members might decrease by $99.6 \%$, according to M2 Poisson model.

Another approach supposes to make a comparison between the CEE countries that are in the EU and Russia and Ukraine. The counterfactual analysis is suitable for measuring of the impact of an intervention (CEE countries entrance in the EU) and the difference-todifference estimator will be provided.

The difference-in-difference estimator approach indicated that the entrance of some CEE countries into the EU had a positive impact on the number of immigrants in the UK that increased by 12 times compared to Russia and Ukraine. The coefficient for year is not significant at $5 \%$ level of significance which implies that even before the entrance into the EU, CEE countries sent many migrants in the UK.
There are no studies that assess the impact of the UK immigrants from the CEE countries on these variables. However, comparisons may be done with the previous studies that evaluate this impact for all UK immigrants. From our point of view, it is more relevant to assess the impact on the CEE countries immigration, because pro Brexit group complained more about the immigration of the citizens from these countries. According to Akaike information criterion, the data are stationary at $5 \%$ level of significance.

According to Bayesian model, the number of immigrants originating from the CEE countries had a positive, but low impact on the real economic growth over 2004-2014.

The number of immigrants in the UK from the CEE countries had a negative, but very low (almost 0 ) influence on the price stability in the UK. This means that the increase in the immigration from the CEE countries will slowly decrease the inflation.

There was a positive correlation between the inflation and the unemployment rate in the

\begin{tabular}{|c|c|c|c|c|}
\hline \multirow[t]{2}{*}{ Tab. 4: } & \multicolumn{4}{|c|}{$\begin{array}{l}\text { Linear regression model based on difference-to-difference estimator } \\
\text { for explaining the number of the UK immigrants (M3) from the main CEE } \\
\text { countries (2004-2014) }\end{array}$} \\
\hline & Variable & Coefficient & t-calculated & $P>|z|$ \\
\hline \multicolumn{2}{|c|}{ Year } & 1.2245 & 1.67 & 0.066 \\
\hline \multicolumn{2}{|c|}{ EU member } & $-25,336.67$ & -2.55 & 0.023 \\
\hline \multicolumn{2}{|c|}{ Year x EU member } & 12.0286 & 2.60 & 0.023 \\
\hline \multicolumn{2}{|l|}{ Constant } & $-2,398.554$ & -1.34 & 0.078 \\
\hline
\end{tabular}

Prob. $>$ chi-square $=0.000$

Source: own 
Bayesian linear regression for explaining the real GDP rate in the UK over 2004-2014

\begin{tabular}{l|c|c}
\multicolumn{1}{c|}{ Variable } & Posterior mean of coefficient & $\begin{array}{c}\text { Posterior standard deviation } \\
\text { of coefficient }\end{array}$ \\
\hline Constant & -5.5202 & 9.7633 \\
\hline Inflation rate & 0.4529 & 0.8220 \\
\hline FDI & 0.0303 & 0.2976 \\
\hline Unemployment rate & -1.6433 & 1.0202 \\
\hline Real interest rate & -0.5633 & 0.79934 \\
\hline Immigrants & 0.0034 & 0.0026 \\
\hline Share of manufacturing & 1.2855 & 0.7867 \\
\hline Variance & 3.0394 & 1.6112 \\
\hline
\end{tabular}

Source: own

\begin{tabular}{l|c|c} 
Tab. 6: & $\begin{array}{c}\text { Bayesian linear regression for explaining the inflation rate in the UK } \\
\text { over 2004-2014 }\end{array}$ \\
\multicolumn{1}{c|}{ Variable } & Posterior mean of coefficient & $\begin{array}{c}\text { Posterior standard deviation } \\
\text { of coefficient }\end{array}$ \\
\hline Constant & 0.2776 & 1.4734 \\
\hline Unemployment rate & 0.3886 & 0.3287 \\
\hline Immigrants & $-9.0654 \mathrm{e}-005$ & $8.9884 \mathrm{e}-004$ \\
\hline Variance & 0.9988 & 0.4437 \\
\hline
\end{tabular}

\begin{tabular}{l|c|c} 
Tab. 7: & $\begin{array}{c}\text { Bayesian linear regression for explaining the unemployment rate in the UK } \\
\text { over 2004-2014 }\end{array}$ \\
\multicolumn{1}{c|}{ Variable } & Posterior mean of coefficient & $\begin{array}{c}\text { Posterior standard deviation } \\
\text { of coefficient }\end{array}$ \\
\hline Constant & 0.5688 & 8.9557 \\
\hline Inflation rate & 0.2639 & 0.3558 \\
\hline Real GDP rate & 0.0769 & 0.3117 \\
\hline Political stability & -5.606 & 4.9654 \\
\hline Competitiveness & 1.2477 & 1.7496 \\
\hline Immigrants & 0.0013 & 0.0048 \\
\hline Variance & 0.8391 & 0.5583 \\
\hline
\end{tabular}

UK over 2004-2014. Ormerod et al. (2013) showed the instability of the empirical Phillips curve on short-run with the endemic cause.

There is a very low and negative impact of the UK immigrants from the CEE countries on the homicide rate. Moreover, we can state that the homicide rate decreased after 2004.
The influence of immigrants on the education spending is positive, but very low. The immigrants' children usually work harder at school to overcome the disadvantage of having English as second language.

The impact of immigrants on the health spending is positive, but quite low. Usually, the 


\section{Ekonomie}

\section{Tab. 8: \\ Bayesian linear regression for explaining the homicide rate in the UK}

over 2004-2014

\begin{tabular}{l|c|c}
\multicolumn{1}{c|}{ Variable } & Posterior mean of coefficient & $\begin{array}{c}\text { Posterior standard deviation } \\
\text { of coefficient }\end{array}$ \\
\hline Constant & 1.8835 & 0.3034 \\
\hline Immigrants & $-5.2288 \mathrm{e}-004$ & $2.7056 \mathrm{e}-004$ \\
\hline Variance & 0.2034 & 0.07764 \\
\hline
\end{tabular}

Tab. 9: Bayesian linear regression for explaining the education spending in the UK over 2004-2014

\begin{tabular}{l|c|c}
\multicolumn{1}{c|}{ Variable } & Posterior mean of coefficient & $\begin{array}{c}\text { Posterior standard deviation } \\
\text { of coefficient }\end{array}$ \\
\hline Constant & 4.8971 & 0.4058 \\
\hline Immigrants & $4.2239 \mathrm{e}-004$ & $2.9988 \mathrm{e}-004$ \\
\hline Variance & 0.2365 & 0.09834 \\
\hline
\end{tabular}

\begin{tabular}{l|c|c} 
Tab. 10: & $\begin{array}{l}\text { Bayesian linear regression for explaining the health spending in the UK } \\
\text { over 2004-2014 }\end{array}$ \\
\multicolumn{1}{c|}{ Variable } & Posterior mean of coefficient & $\begin{array}{c}\text { Posterior standard deviation of } \\
\text { coefficient }\end{array}$ \\
\hline Constant & 8.0475 & 0.4533 \\
\hline Immigrants & 0.0016 & $3.5673 \mathrm{e}-004$ \\
\hline Variance & 0.5036 & 0.1584 \\
\hline
\end{tabular}

immigrants are young people that are able to work and have no major health problems.

All in all, we validated the assumptions for the CEE countries emigrants in the UK that were previously checked in literature for the all UK immigrants. These showed that arguments of pro Brexit group regarding immigration are not, actually, plausible. The UK immigrants coming from the CEE states slowly stimulated the economic growth in the UK and had a low positive influence on the unemployment. They contributed to the prices stability and lower crime rate and did not significantly affect the increase in health and education spending. So, there are reasons not to control too strictly the CEE countries immigrations after Brexit.

\section{Discussion}

As expected, the EU membership had a positive impact on the emigration process to the UK. Many EU states put restrictions to migrants from new EU members that entered in 2004 and 2007, excepting Cyprus and Malta, considering the concerns about negative impact of migration on their labour market. Only the UK, Ireland and Sweden decided to open their labour market immediately after 2004 (Kahanec et al., 2009) and many migrants came to work. The UK proposed only one restriction consisting in the adoption of a scheme that asks for the registration of the EU-28 workers with the Home Office.

The increases in the GDP per capita in the mentioned CEE countries had a very low and 
negative impact on the migration towards the UK. As we expected, the countries with low GDP per capita send the migrants to developed countries like the UK. A lower GDP per capita is related to higher poverty and less available jobs. All the CEE countries had lower GDP per capita than UK and a big part of migrants came to this state. This migrants' behaviour is explained by economic reasons which is consistent with other results from literature. For example, Hatton and Wiliamson (2005) proved the correlation between changes in the GDP per capita in host country and the migration flow in the destination country that is richer. If the GDP per capita in the states from West Europe increases by 10 percent, the migration to the US decreases by 12.6 percent. In our empirical study, if the GDP per capita in the CEE countries doubles, the number of migrants to the UK decreases by only 0.04 percent. If these results are compared with the previous ones for EU membership, we can state that CEE migrants were attracted more by the jobs opportunities in the UK than by the poverty in the origin country.

The negative impact of unemployment in the origin country on the number of immigrants in the UK might be explained by different arguments. The fact that the CEE emigrants are not necessarily represented by people that do not have any job in the origin country might be an explanation for these results. They were looking for a higher salary in the UK, while the wage in the origin country was low. The recent economic literature is focused on the brain drain phenomenon in the Central and Eastern Europe (Ienciu \& Ienciu, 2015). High skilled labour resources go to developed countries where the salaries are higher. The public policies in the origin countries are not in favour of qualified adults and the brain drain represents an important capital loss. On the other hand, the brain drain might have long run positive effects in terms of remittances sent to origin countries (Kim \& Lee, 2016).

The lack of statistical significance of the distance between London and the capitals of CEE countries is in line with other empirical findings from literature. In this context, Pytlikova (2006) indicated that the distance has a low influence in selecting emigrants' destination country in the last decades.

The positive impact of EU membership on the migration behaviour in the CEE countries was also confirmed by the difference-indifference approach. Actually, the political context after 1990s when CEE states made the transition from communist regime to a market economy and a democratic society changed the migration behaviour. Since 1990 these CEE countries sent many emigrants to developed states from the West of Europe. The 2004 EU enlargement intensified the labour mobility from seven of the CEE countries to the UK. The 2007 enlargement increased the number of immigrants from Romania and Bulgaria in the UK (Pemberton \& Scullion, 2013).

The positive impact of immigration on the real economic growth is consistent with Petroff (2016) who showed that immigration stimulates the economic growth in the UK. Moreover, according to expectations, the FDI was an engine of the economic growth. The unemployment rate negatively affected the GDP growth, while the highest positive impact on economic growth was registered by the share of manufacturing. According to Cadman et al. (2016), manufacturing has a central position in British economy, even if its importance declined over the past decades. In 1948, its contribution was about 36 percent of GDP, while now it is about 10 per cent. The number of employees in the manufacturing sector declined faster than the output share, but the new technology made this sector more productive because of the higher value goods. Exports are the principal weak spot for manufacturing sector, being hit by the slowdown in the euro area. Domestic demand is rather strong in the UK, but the overall industry was smaller than it was before the downturn.

The negative impact of immigration on inflation was also obtained by Frattini (2014) who showed that immigration contributed to the inflation reduction for goods and services over 1995-2006. Sa (2015) showed that there is no empirical evidence that the immigration had a positive impact on house pricing. The same result was also found by Wadsworth (2012). His study also shows no impact on rents, while the immigrants are much more likely to be in private rental accommodation in comparison with UKborn individuals. According to Wadsworth (2012) $5.5 \%$ of immigrants represent $10.9 \%$ of workers in the construction industry. That is relatively fewer than in other sectors of British economy and it has no effect on cost of construction. 
The positive relationship between the inflation and unemployment was also described by Batini et al. (2005) over 1987-1999. The number of immigrants had a positive, but very low impact on the unemployment rate in the UK. Contrary to expectations, the political stability was negatively correlated to unemployment. It was shown that the political stability did not solve the problem of unemployment in the UK. Dustmann et al. (2003) showed a positive impact of immigration on the unemployment rate over 1971-1991. Regarding the EU immigrants, the Centre for Economic Performance confirmed our results by showing that there is a little evidence that EU migrants had a positive effect on the UK unemployment. And more, according to the Department for Business Innovation \& Skills (February 2015) migrants fill the gaps in the UK workforce. The jobs taken by the immigrants would be either empty or filled with under-qualified staff. We found no impact of immigration on homicide rate, the conclusion being in line with Bell et al. (2013) who showed that there was no impact of immigration on crime rate. We proved the low impact of immigration on education spending. Geay et al (2013) also showed the lack of significance of immigration on education spending in the UK.

Immigration in the UK also had a very low effect on health spending. A similar result was obtained by Wadsworth (2013) who found little evidence for the positive impact of EU immigration on the health spending. A possible explanation would be the fact that EU immigrants are younger and do not need special medical care.

Our findings confirmed the results of previous studies that were also based on empirical researches. The CEE immigrants played an important role in the UK economic growth with a very low impact on unemployment rate, health and education spending or crime rate, Moreover, the immigrants contributed to prices stability in the UK. After Brexit, if policies that restrict the access of immigrants from CEE countries on the UK labour market will be implemented, the economic growth and prices stability will be negatively affected.

\section{Conclusions}

As expected, in this paper we showed that the number of the UK immigrants from the CEE countries that are in the European Union significantly increased due to the EU membership. In case of Brexit, this number might decrease by 2 times, according to mixed-effects Poisson model. Compared to Russia, and Ukraine, the number of CEE emigrants increased, in average, by 13 times over the period 2004-2014 because of the EU membership. The empirical research is limited by the data availability. For the rest of the CEE countries the number of UK immigrants is not provided by the Office for National Statistics.

Our empirical evidences showed that CEE emigrants to the UK brought a positive impact on the UK economic growth, price stability and lower homicide rate. On the other hand, migration from the CEE states slightly increased the unemployment rate, health and education spending. The results are consistent with previous studies for all UK immigrants. A lower number of EU immigrants was also anticipated by Portes and Forte (2016).

Two main migration policies could be considered after Brexit. The UK imposed a cap of 20,700 Tier 2 visas per year. If this restriction will be applied to EU nationals, the number of EU workers will diminish. A second policy supposes that most of the non-EU nationals with Tier 2 visas might stay permanently in the UK only in case of a minimum earning of $£ 35,000$ per year. Most of the migrants earn less than this valueand could stay maximum 6 months in the UK. If this restriction is applied, most of the EU migrants have to leave the UK or stay less time (Vargas-Silva, 2016). So, our empirical findings are in line with the current migration policies that could apply after Brexit. If the government will chose to drop these restrictions for the EU migrants, the situation of migrants might change. Moreover, all the studies regarding Brexit underlined the uncertainty regarding the UK policies and the number of immigrants.

After Brexit, a policy of limiting the migration would lower the economic growth trend, even if GDP per capita might not be affected to the same magnitude. The UK policy options after Brexit might be various. The Norway or Switzerland models will encourage free movement of persons, goods, services and capital, but bilateral agreements with few countries will negatively affect the economic performance of the UK. If the UK will not implement policies for a lower reduction of immigration, the productivity and the labour market flexibility will cause problems to the UK economy that might face more frequent 
recessions. Our recommendation consists in policies that more focus on the labour market flexibility after Brexit than policies that offer measures regarding the origin countries of the immigrants.

Our empirical findings could be a suitable support in designing new migration policies for the UK, if this country will not be interested in reducing the number of immigrants from CEE countries, because most of them are workers that contribute to the UK economic growth. In a future research, a comparison between our predictions regarding the reduction in the number of immigrants and the real decrease is necessary.

This study might be also continued by considering other determinants of immigration in the UK. The poverty in the CEE countries might explain the orientation towards the UK, but long data series for poverty rate are still not available for all the CEE countries. In the context of Brexit's impact on the UK immigration, the emigrants from the CEE countries should take into account other EU countries as destination. The number of the actual UK immigrants might be influenced by the policy measures after Brexit, but the chances to leave the UK are lower for stable immigrants.

\section{References}

Aichele, R., \& Felbermayr, G. (2015). Kosten und Nutzeneines Austritts des Vereinigten Königreichsaus der Europäischen Union. Munich: Munich University.

Balcerzak, A. P. (2016). Multiple-criteria Evaluation of Quality of Human Capital in the European Union Countries. Economics and Sociology, 9(2), 11-27. doi:10.14254/2071789X.2016/9-2/1.

Battiston, D., Dickens, R., Manning, A., \& Wadsworth, J. (2013). Immigration and the Access to Social Housing in the UK (CEP Discussion Paper, 1264). 1-51.

Batini, N., Jackson, B., \& Nickell, S. (2005). An open-economy new Keynesian Phillips curve for the UK. Journal of Monetary Economics, 52(6), 1061-1071. doi:10.1016/j. jmoneco.2005.08.003.

Bell, B., Fasani, F., \& Machin, S. (2013). Crime and Immigration: Evidence from Large Immigrant Waves. Review of Economics and Statistics, 95(4), 1278-1290. doi:10.1162/rest_a_00337.

Bell, B., Machin, S., \& McNeil, R. (2013). Immigration and Crime: Evidence for the UK and Other Countries. Migration Observatory Briefing. COMPAS: University of Oxford.

Booth, S. (2015, March 25). What would Brexit mean for immigration? Open Europe. Retrieved from http://openeurope.org.uk/today/ blog/what-would-brexit-mean-for-immigration/.

Borońska-Hryniewiecka, K. (2016). A WinWin Situation? What to Make of the EU-UK Deal. PISM Strategic Files, 84, 1-6.

Boubtane, E., Dumont, J. C., \& Rault, C. (2015). Immigration and Economic Growth in the OECD Countries 1986-2006 (CESIFO Working Paper, 5392). 1-36. doi:10.1093/oep/ gpw001.

Boswell, C. (2016). Migration: would limiting the free movement of labour be good or bad? In C. Jeffery, \& R. Perman (Eds.), Britain's Decision: Facts and Impartial Analysis for the EU referendum on 23 June 2016. Edinburgh: The David Hume Institute.

Cadman, E., Bernard, S., \& Pearson, T. (2016, May 6). The UK economy at a glance. Financial Times. Retrieved from: https://ig.ft. com/sites/numbers/economies/uk.

Čajka, P., Jaroszewicz, M., \& Strielkowski, W. (2014). Migration incentives and flows between Belarus, Moldova, Ukraine and the European Union: A forecasting model. Economics and Sociology, 7(4), 11-25. doi:10.14254/2071-789x.2014/7-4/1.

Chu, B. (2016, March 22). Post-Brexit Britain would need to keep migration high to prevent economic fallout. The Independent. Retrieved from: http://www.independent.co.uk/ news/uk/politics/eu-referendum-brexit-impactlimited-only-if-uk-welcomes-large-numbers-ofmigrants-a6944716.html.

Hall, M. (2016, April 18). Britain has 'too many migrants' New poll boosts fight to quit EU. Daily Express. Retrieved from: http://www. express.co.uk/news/uk/661872/Poll-migrationEU-referendum-Boris-Cameron-Brexit.

Department for Business Innovation \& Skills. (2015). The impacts of migrant workers on UK businesses (BIS Research Paper, 217). 1-63.

Duczynski, P. (2000). Capital Mobility in Neoclassical Models of Growth: Comment. American Economic Review, 90(3), 687-694. doi:10.1257/aer.90.3.687.

Dustmann, C., Fabbri, F., Preston, I., \& Wadsworth, J. (2003). The local labour market effects of immigration in the UK. UK Home Office, 6(3), 1-67. 
Dustmann, C., \& Frattini, T. (2014). The Fiscal Effects of Immigration to the UK. Economic Journal, 124, 593-643. doi:10.1111/ ecoj.12181.

Dustmann, C., Fabbri, F., \& Preston, I. (2005). The Impact of Immigration on the UK Labour Market. Economic Journal, 115(507), 324-341. doi:10.1111/j.1468-0297.2005.01038.x.

Dhingra, S., Ottaviano, G., Sampson, T., \& Van Reenen, J. (2016). The Consequences of Brexit for UK Trade and Living Standards. CEP Brexit Analysis. 2, 1-15.

Ebell, M., \& Warren, J. (2016). The longterm economic impact of leaving the EU. National Institute Economic Review, 236(1), 121-138. doi:10.1177/002795011623600115.

El-Sayyad, G. M. (1973). Bayesian and classical analysis of Poisson regression. Journal of the Royal Statistical Society, 35(3), 445-451.

Farmer, K., \& Schelnast, M. (2013). Factor Proportion, Inter-Sectoral Trade, and Product Life Cycle. In Growth and International Trade (pp. 215-233). Berlin Heidelberg: Springer. doi:10.1007/978-3-642-33669-0_10.

Felbermayr, G. J., Hiller, S., \& Sala, D. (2010). Does immigration boost per capita income? Economics Letters, 107(2), 177-179. doi:10.1016/j.econlet.2010.01.017.

Frattini, T. (2014). Impact of migration on UK consumer prices. Retrieved from https:// www.gov.uk/government/publications/impactof-migration-on-uk-consumer-prices.

Geay, C., McNally, S., \& Telhaj, S. (2013). Non-Native Speakers in the Classroom: What are the Effects on Pupil Performance? Economic Journal, 123(570), 281-307. doi:10.1111/ecoj.12054.

Gibbons, R. D., Segawa, E., Karabatsos, G., Amatya, A. K., Bhaumik, D. K., Brown, C. H., \& Mann, J. J. (2008). Mixed-effects Poisson regression analysis of adverse event reports: The relationship between antidepressants and suicide. Statistics in medicine, 27(11), 18141833. doi:10.1002/sim.3241.

Giovanni, J., Levchenko, A., \& Ortega, F. (2012). A Global View of Cross-Border Migration. CReAM Discussion Paper Series, 18(12), 1-50.

Giuntella, O., Nicodemo, C., \& Vargas Silva, C. (2015). The Effects of Immigration on NHS Waiting Times (University of Oxford Working Paper, 9351). 1-53.

Godwinn, A. (2016). Brexit and immigration. Economic Outlook, 40(2), 20-25. doi:10.1111/1468-0319.12215.
Grosu, R. M., \& Dinu, V. (2016). The migration process of Romanians to Andalusia, Spain. Focus on socio-economic implications. E\&M Ekonomie a Management, 19(2), 21-36. doi:10.15240/tul/001/2016-2-002.

Hatton, T. J., \& Williamson, J. G. (2005). What fundamentals drive world migration? In Poverty, international migration and asylum (pp. 15-38). Palgrave Macmillan UK.

Hilber, C. (2015). UK Housing and Planning Policies. CEP Election Analysis, 3, 1-15.

Hirsch, S. (2009). The Product Cycle Model of International Trade - A Multi-Country Cross-Section Analysis. Oxford Bulletin of Economics and Statistics, 37(4), 305-317. doi:10.1111/j.1468-0084.1975.mp37004004.x.

lenciu, N. M., \& Ienciu, I. A. (2015). Brain drain in Central and Eastern Europe: new insights on the role of public policy. Southeast European and Black Sea Studies, 15(3), 281299. doi:10.1080/14683857.2015.1050799.

ITV. (2016, April 13). Finding the facts: The truth behind referendum claims on immigration. ITV Report. Retrieved from: http://www.itv.com/ news/2016-04-13/finding-the-facts-the-truthbehind-referendum-claims-on-immigration/.

Jäger-Ambrożewicz, M., \& Jürgen, M. (2012). Finanzmarkt - Beschleuniger oder Bremse des Wachstums? In Institut der deutschenWirtschaft Köln (Ed.), Wirtschaftswachstum?! - Warumwirwachsensollten und warumwirwachsenkönnen (pp. 173-188). Cologne: IW-Studien.

Kahanec, M., Zaiceva, A., \& Zimmermann, K. F. (2009). Lessons from migration after EU enlargement. In EU labor markets after post-enlargement migration (pp. 3-45). Berlin, Heidelberg: Springer.

Kim, J., \& Lee, N. Y. (2016). The Effect of High-Skilled Emigration, Foreign Direct Investment, and Policy on the Growth Rate of Source Countries: A Panel Analysis. East Asian Economic Review, 20(2), 229-275. doi:10.11644/kiep.eaer.2016.20.2.310.

Lelek, J. (2014). Trend Analysis of Human Resources Development Representing the Base for Researchers in Selected Economies. Journal of Competitiveness, 6(1), 71-86. doi:10.7441/joc.2014.01.05.

Lodewyckx, I., Timmerman, C., \& Wets, J. (2010). From nation state to migration state. Economics and Sociology, 3(2), 9-22.

Merkevicius, J., Davidaviciene, V., Raudeliuniene, J., \& Buleca, J. (2015). Virtual 
organization: specifics of creation of personnel management system. E\&M Ekonomie a Management, 18(4), 200-211. doi:10.15240/ tul/001/2015-4-014.

Miłaszewicz, D., Milczarek, A., Nagaj, R., Szkudlarek, P., \& Zakrzewska, M. (2015). Determinants of polish international migration in the area of the European union after 2004. Journal of International Studies, 8(3), 62-78. doi:10.14254/2071-8330.2015/8-3/5.

Migration Advisory Committee. (2014). Migrants in low-skilled work: The growth of EU and non-EU labour in low-skilled jobs and its impact on the UK. Migration Advisory Committee Report. July(2014), 1-356.

Office for Budget Responsibility. (2013). Fiscal Sustainability Report. Retrieved from http://budgetresponsibility.org.uk/docs/dlm_ uploads/2013-FSR_OBR_web.pdf.

Office for Budget Responsibility. (2015). Economic and Fiscal Outlook. Retrieved from http://budgetresponsibility.org.uk/efo/ economic-fiscal-outlook-july-2015/.

Ormerod, P., Rosewell, B., \& Phelps, P. (2013). Inflation/unemployment regimes and the instability of the Phillips curve. Applied Economics, 45(12), 1519-1531. doi:10.1080/00 036846.2011.628299.

Ortega, F., \& Peri, G. (2014). Openness and income: The roles of trade and migration. Journal of International Economics, 92(2), 231-251. doi:10.1016/j.jinteco.2013.11.008.

Ottaviano, G., Peri, G., \& Wright, G. (2016). Immigration, Trade and productivity in services (CEP Discussion Paper. 1353). 1-53.

Pemberton, S., \& Scullion, L. (2013). The policies and politics of managed migration: Exploring mature labour migration from Central and Eastern Europe into the UK. Journal of Ethnic and Migration Studies, 39(3), 443-461. doi:10.1080/1369183x.2013.733863.

Petroff, A. (2016, April 6). The truth about UK immigration. CNN. Retrieved from http:// money.cnn.com/2016/04/07/news/economy/ uk-immigration-brexit-eu-referendum/.

Pilinkiene, V. (2016). Trade Openness, Economic Growth and Competitiveness. The Case of Central and Eastern European Countries. Inzinierine Ekonomika-Engineering Economics, 27(2), 185-194. doi:10.5755/j01. ee.27.2.14013.

Portes, J. (2016). Immigration, Free Movement and the UK Referendum. NIESR Review, 236, 1-9.
Portes, J., \& Forte, G. (2016, December 7). The Economic Impact of Brexit-induced Reductions in Migration. National Institute of Economic and Social Research. Retrieved from http://ukandeu.ac.uk/wp-content/uploads/ 2016/12/The-economic-impact-of-Brexitinduced-reductions-in-migration.pdf.

Pytlikova, M. (2006). Where Did Central and Eastern European Emigrants Go and Why. Aarhus: University of Aarhus, School of Business, CIM and Department of Economics. Retrieved from http://pure.au.dk//portal/ files/482/6_phdchap4_MP.pdf.

PwC. (2016). Leaving the EU: Implications for the UK economy. Retrieved from http:// news.cbi.org.uk/news/leaving-eu-would-causea-serious-shock-to-uk-economy-new-pwcanalysis/leaving-the-eu-implications-for-the-ukeconomy/.

Rebelo, S. (1991). Long-Run Policy Analysis and Long-Run Growth. Journal of Political Economy, 99(3), 500-521. doi:10.1086/261764.

Robinson, B. (2015). The Brexit and investments. Retrieved from http://www. newstatesman.com/economics/2015/04/brexitand-investments-what-would-exit-vote-mean.

Romer, P. M. (1994). The Origins of Endogenous Growth. Journal of Economic Perspectives, 8(1), 3-22. doi:10.1257/jep.8.1.3.

Stefaniak-Kopoboru, J., \& Kuczewska, J. (2016). Export Specialization in Services of the Visegrad Countries. Equilibrium. Quarterly Journal of Economics and Economic Policy, 11(2), 265-284. doi:10.12775/ EQUIL.2016.012.

Taylor, M. S., Grossman, G. M., \& Helpman, E. (1993). Innovation and Growth in the Global Economy. Economica, 60(239), 373-380. doi:10.2307/2554862.

Rumpel, P., Slach, O., \& Koutský, J. (2013). Shrinking cities and governance of economic reneration: the case of Ostrava. E\&M Ekonomie a Management, 16(2), 113-128.

Ruparel, R. (2016, April 13). Where next? A liberal, free-market guide to Brexit. Open Europe. Retrieved from http://openeurope.org. uk/intelligence/britain-and-the-eu/guide-to-brexit/.

Sa, F. (2015). Immigration and House Prices in the UK. Economic Journal, 125(587), 1393-1424. doi:10.1111/ecoj.12158.

Springford, J. (2013). Is immigration a reason for Britain to leave the EU? Retrieved from https://www.cer.org.uk/sites/default/files/ publications/attachments/pdf/2013/pb_imm_ uk_27sept13-7892.pdf. 


\section{Ekonomie}

Staiger, U. (2016). Migration, the lightning rod of the EU referendum. Retrieved from https://www.opendemocracy.net/brexit divisions/ uta-staiger/migration-lightning-rod-of-eureferendum.

The Migration Observatory. (2012). Britain's '70 Million'Debate: A Primer on Reducing Immigration to Manage Population Size. Retrieved from https://www.researchonline.org.uk/sds/search/ go.do $\% 3 \mathrm{Bjsessionid}=8 \mathrm{D} 978 \mathrm{~F} 41423 \mathrm{CCF}$ 81A246B4615CD350CB?action=document\& ref=B27579.

Tilford, S. (2016). Britain, immigration and Brexit. CER Bulletin, 105, 1-2.

Vargas-Silva, C. (2016). EU Migration to and from the UK After Brexit. Intereconomics, 51(5), 251-255. doi:10.1007/s10272-016-0613-z.

Wadsworth, J. (2012). Immigration and the UK labour market: the latest evidence from economic research. CEP Policy Analysis, CEPPA014, 1-9.

Wadsworth, J. (2013). Mustn't Grumble: Immigration, Health and Health Service Use in the UK and Germany. Fiscal Studies, 34(1), 55-82. doi:10.1111/j.1475-5890.2013.00177.x.

Wadsworth, J. (2015). Immigration and the UK Labour Market. CEP Election Analysis, 1, 1-15.

Wadsworth, J., Dhingra, S., Ottaviano, G., \& Van Reenen, J. (2016). Brexit and the Impact of Immigration on the UK. CEP Brexit Analysis, 5, 1-22.
Woodford. (2016). The economic impact of 'Brexit. Retrieved from https://woodfordfunds. com/economic-impact-brexit-report/.

Vitunskiene, V., \& Serva, E. (2015). Shifts in Lithuania's Agri-food Industry Export Competitiveness: a Comparative Analysis Versus High- and Medium-high Technology Manufacturing Industries. Oeconomia Copernicana, 6(1), 7-31. doi:10.12775/OeC.2015.001.

\section{Senior Researcher Mihaela Simionescu, Ph.D.} Romanian Academy Institute for Economic Forecasting mihaela_mb1@yahoo.com

Assoc. Prof. Yuriy Bilan, Ph.D. Tomas Bata University in Zlín Faculty of Management and Economics Centre for Applied Economic Research yuriy_bilan@yahoo.co.uk

Assoc. Prof. Ing. Luboš Smrčka, CSc. University of Economics, Prague Faculty of Business Administration smrckal@vse.cz

Ing. Zuzana Vincúrová, PhD. Pan-European University Faculty of Economics and Business Zuzana.vincurova@paneurouni.com 


\title{
Abstract
}

\section{THE EFFECTS OF EUROPEAN ECONOMIC INTEGRATION AND THE IMPACT OF BREXIT ON THE UK IMMIGRANTS FROM THE CEE COUNTRIES}

\author{
Mihaela Simionescu, Yuriy Bilan, Luboš Smrčka, Zuzana Vincúrová
}

Considering the debates regarding lower increase in the economic growth after Brexit, the main objective of this paper is to measure the positive impact of economic integration of Central and Eastern European (CEE) countries on the UK economy and the effect of Brexit on the immigration from these countries to the UK. The European Union membership of some CEE countries increased, in average, the number of the UK immigrants by 12 times in the period 2004-2014 compared to the group of countries formed by Russia and Ukraine. The empirical findings show positive economic effects of immigration on the UK's economy, even if the pro Brexit group claimed that a control of immigration is necessary. CEE countries emigrants stimulated the UK economic growth, price stability and reduced the homicide rate. The effects of immigration on the unemployment rate, health and education spending were positive, but very low. According to mixed-effects Poisson models estimations, after Brexit the number of the UK immigrants from the CEE countries that are member of the EU might decrease by 2 times. This significant decline in immigration might impose austerity measures, because of the fall in the economic growth trend with negative impact on the UK economy. Therefore, we recommend policies that focus more on high-skilled labour force than on the reduction of the number of immigrants. The UK should propose measures to slow the expected immigration decline in order to alleviate economic issues like decline in economic growth, decrease in labour productivity, cutting backs on public services.

Key Words: Immigrants, CEE countries, economic integration, Brexit, Poisson regression.

JEL Classification: C51, C53, J61.

DOI: 10.15240/tul/001/2017-1-003 